\title{
Response of Junior High School Students About Online Learning of PJOK Lessons in The Time of The Covid-19 Pandemic
}

\author{
Fikri Firmansyah Alam ${ }^{1, *}$, Rina Maryanti ${ }^{2}$ \\ ${ }^{1}$ Fakultas Pendidikan Olahraga dan Kesehatan, Universitas Pendidikan Indonesia, Indonesia \\ ${ }^{2}$ Fakultas Ilmu Pendidikan, Universitas Pendidikan Indonesia, Indonesia \\ *Corresponding author: fikri.firmansyah0502@upi.edu
}

\begin{abstract}
Abstrak: Tujuan kegiatan ini adalah untuk mengetahui tanggapan siswa SMP terhadap pembelajaran daring mata pelajaran PJOK di masa pandemi Covid 19. Penelitian ini menggunakan metode deskriptif kualitatif. Teknik pengumpulan data menggunakan kuesioner daring. Kuesioner disebarkan dalam bentuk link google form melalui WhatsApp Group. Responden kegiatan yaitu siswa-siswi SMP kelas 7 sebanyak 20 siswa. Tempat dilakukannya kegiatan adalah di SMPN 4 Bandung. Berdasarkan hasil respon siswa, sebagian besar siswa memberikan respon yang kurang menyukai pelaksanaan pembelajaran PJOK daring. Pemahaman siswa terhadap materi yang disampaikan guru selama pembelajaran daring kurang dapat dipahami. Sebagian besar respon siswa menyatakan bahwa pembelajaran PJOK daring tidak menyenangkan karena dilakukan sendiri di rumah dan tidak dapat berinteraksi dengan guru maupun teman-teman, sehingga siswa merasa bosan dibandingkan pembelajaran PJOK secara luring. Dalam mengatasi kesulitan belajar PJOK daring, diperlukan media pembelajaran daring yang lebih interaktif, sehingga tingkat interaksi antara guru dan siswa secara daring sama dengan tingkat interaksi siswa secara luring.
\end{abstract}

Kata kunci : Pembelajaran daring, pembelajaran PJOK, interaksi siswa.

\begin{abstract}
The purpose of this activity was to determine the responses of junior high school students to online learning of PJOK subjects during the covid 19 pandemic. This study used a qualitative descriptive method. Data collection techniques using online questionnaires. The questionnaire was distributed in the form of a google form link via WhatsApp Group. Observation respondents were 7th grade junior high school students as many as 20 students. The place where the observation was conducted was at SMPN 4 Bandung. Based on the results of student responses, most of the students gave a response that did not like the implementation of online learning of PJOK. Students' understanding of the material presented by the teacher during online learning is less understandable. Most of the student responses stated that online learning of PJOK was not fun because it was done alone at home and could not interact with teachers or friends, so students felt bored compared to offline learning PJOK. In overcoming the difficulties of online learning of PJOK, a more interactive online learning media is needed, so that the level of interaction between teachers and students online is the same as the level of student interaction offline.
\end{abstract}

Keywords : Online learning, PJOK learning, student interaction

\section{Introduction}

At the end of 2019, the whole world was facing a very big outbreak with the emergence of the coronavirus. This epidemic has attacked all countries, including Indonesia. This deadly virus attacks the human respiratory system and is transmitted through saliva. This

Volume 3, Nomor 1, Maret 2022 | 20

Response of Junior High School Students About Online Learning of PJOK Lessons

in The Time of The Covid-19 Pandemic

Fikri Firmansyah Alam, Rina Maryanti

https://doi.org/10.26874/jakw.v3i1.123 
coronavirus outbreak has an impact on all aspects of life, without exception the world of education. In the realm of education, teaching and learning activities must take place remotely, namely through an online learning system. Learning that is actually carried out by direct interaction between teachers and students (face to face), is now turning into online learning (in the network). As stated by Herlina \& Maman (2020), learning which has been carried out face-to-face, suddenly has to be done online.

The impact of the spread of the Covid-19 virus in the world of education is changing the system learning from face-to-face or offline switching to distance learning systems remote or called online which affects all subjects, one of which is PJOK. PJOK learning is a physical activity that encourages humans to develop social, physical, and spiritual potential (Latifah et al., 2021).

This becomes an obstacle in learning, especially for subjects that require physical activity, such as PJOK subjects. As stated by Irfan and Agung (2021) that health and recreation physical education is one that has an impact on the Covid 19 pandemic, Physical education which is generally carried out together in open spaces is now carried out differently remotely and is carried out at each other's homes. Physical Education for Sports and Health (PJOK) is a subject with a lot of physical activity such as running, throwing, hitting, and jumping (Dyah et al., 2020).

Online Learning of PJOK is a new thing for both teachers and students. Teacher are required to be more creative so that online learning of PJOK can run well. The online learning model demands the creativity and skills of the teacher using technology (Mansyur, 2020). In addition, students are also expected tocan access applications used in online learning, such as Zoom, Google Classroom, and other applications.

In addition to the above applications, there are also other internet technologies in the field of education as a means of learning, namely e-learning. Hendra Ramadhona (2016) states that with this technology a teacher teaches in front of a computer or laptop, while students follow the learning from another computer or laptop in a different place and at the same time. This can make it easier for students to find information via the internet.

This online learning is a solution when natural disasters such as the corona outbreak are currently being experienced by most countries in the world. Like now, when the government sets a social distancing policy, online learning is the only choice of learning method that can be done. However, factors from schools and parents must be considered so that students need to receive education can be well received by students. The continuity of education during the

Volume 3, Nomor 1, Maret 2022| 21 
pandemic will depend on various factors, such as the level of school preparation, the readiness of parents/families, and the readiness of teachers (Yunitasari, 2020).

Physical education is an educational process that utilizes physical movement activities as a means of achieving national education goals (Fatkhur et al., 2021). Online Learning of PJOK during the COVID-19 pandemic must create effective education. As stated in Santoso, 2020 that learning at home or online learning is an effective way to prevent the spread of COVID-19 in the world of education. Online learning is carried out as a substitute for offline learning in schools so that learning activities can still be carried out effectively. Given the conditions of learning that must be done online, schools are trying to create effective online learning with the facilities and abilities of the educators they have, now they must have good information technology (IT) skills. Educators have a very decisive role in the success of this online learning. Educators must create creative, innovative, and recreational learning methods that stimulate students to be willing to be actively involved in online learning and feel the meaning of learning (Dyah et al., 2020).

\section{Method}

This study uses a descriptive method with a qualitative approach. Technique Data collection carried out in this study was by using the instrument data collection in the form of online questionnaires. The questionnaire consists of several points questions about online learning of PJOK as listed in Table 1.

Table 1. Online Question Instruments

\begin{tabular}{|l|l|}
\hline No. & \multicolumn{1}{|c}{ Questions } \\
\hline 1. & Before the Pandemic, how many hours on average did you study/do Sports ? \\
\hline 2. & $\begin{array}{l}\text { During the Pandemic and learning goes Online, how many hours on average do you } \\
\text { study / do exercise at home ? }\end{array}$ \\
\hline 3. & What are your difficulties in learning sports online? \\
\hline 4. & Do you understand the Sports material delivered by the teacher directly? online? \\
\hline 5. How do you feel about learning Sports Online? \\
\hline 6. & Are there any physical benefits that are felt after learning Sports by online? \\
\hline 7. Did your parents help you learn sports at home? \\
\hline 8. In your opinion, has it been effective to learn sports online ?
\end{tabular}


Questionnaires are distributed in the form of a google form link by students/observer to junior high school students via WhatsApp Group. The data generated is in the form of transcripts regarding the effectiveness of online learning of PJOK, students' understanding of the material presented by the teacher, parental support during online learning of PJOK. The results obtained later concluded. The target respondents in this study were 7th grade junior high school students as many as 20 students. The place where this observation was conducted is at SMPN 4 Bandung.

\section{Results And Discussion}

This observation was carried out when students had participated in online learning of PJOK. The respondents were asked to fill out the questionnaire which found in the google form with a link that has been distributed by observer. Fig. 1-8 show a frequency diagram of junior high school students' responses about online learning subjects in PJOK in the time of the covid 19 pandemic, based on the online question instruments according to Table 1.

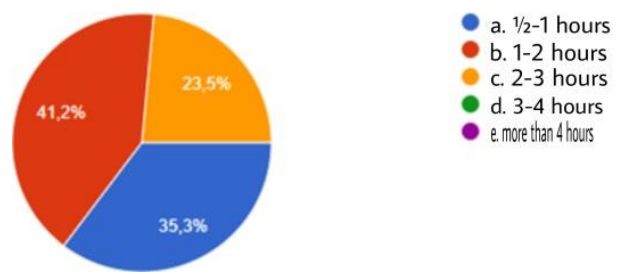

Fig. 1. Before the Pandemic, how many hours on average did you study/do sports.

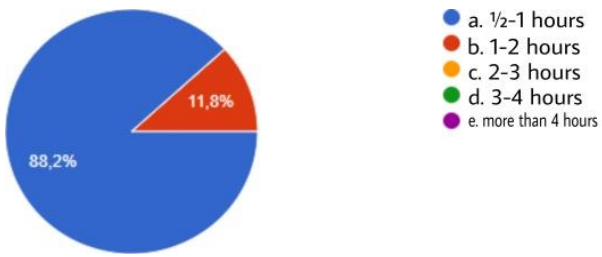

Fig. 2. After the Pandemic, how many hours on average do you study/do sports

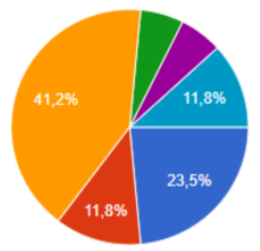

$$
\begin{aligned}
& \text { a. subject matter is difficult to understand } \\
& \text { b. hard to concentrate } \\
& \text { c. boring (because exercising alone at } \\
& \text { home) } \\
& \text { d. unable to practice sports with friends (in } \\
& \text { groups) } \\
& \text { e. cant' interact directly with the teacher } \\
& \text { f. lazy (because there are no sports equipment } \\
& \text { at home and the place is not spacious) }
\end{aligned}
$$

Fig. 3. Difficulty online learning of PJOK

Based on the results of student respondents, that for the duration of online learning of PJOK, most students (88.2\%) study for -1 hour each meeting as shown in Fig. 2. Online learning of PJOK has a shorter duration than offline learning of PJOK most of them $(44.4 \%)$

Volume 3, Nomor 1, Maret 2022 | 23

Response of Junior High School Students About Online Learning of PJOK Lessons

in The Time of The Covid-19 Pandemic

Fikri Firmansyah Alam, Rina Maryanti

https://doi.org/10.26874/jakw.v3i1.123 
study 1-2 hours per meeting as seen in Fig. 1. According to Fig. 3, some of the factors that causes the duration of online learning of PJOK to be shorter than offline, one of which is students feel bored because they do sports activities alone at home (41.2\% of students) and also limited sports equipment and land when learning PJOK online at home.

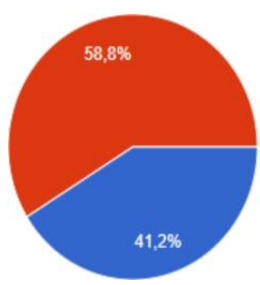

a. understand

b. not really understand

c. not understand

Fig. 4. Understanding of sports material delivered by online teachers

In addition, the less regular conditioning of the class goes along with the shorter it is learning time in the application of the online learning system causes the material to be delivered by the teacher to be $58,8 \%$ was not understood by the students as shown in Fig. 4 . Teachers as one component of educators must be able to understand how children learn and create a learning process that allows students to develop their abilities and character types (Azhar \& Maryanti, 2021).

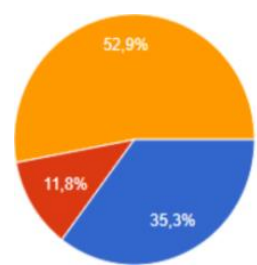

Fig. 5. Student responses to online POJK learning

It is known based on the results of the questionnaire in Fig. 5, that as many as $52.9 \%$ of students feel normal about the response to Online learning of PJOK, 35.3\% feel happy and $11.8 \%$ feel dissatisfied with online learning of PJOK.

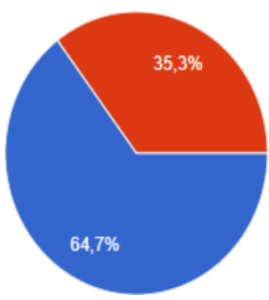

$$
\begin{aligned}
& \text { a. feel a little } \\
& \text { b. feel it } \\
& \text { c. really feel }
\end{aligned}
$$

Fig. 6. Physical benefits that students feel after learning Sports Online 
The physical benefits that are felt by students when implementing online sports learning are $64.7 \%$ slightly feel the benefits and $35.3 \%$ feel the physical benefits of online learning of PJOK as shown in Fig. 6.

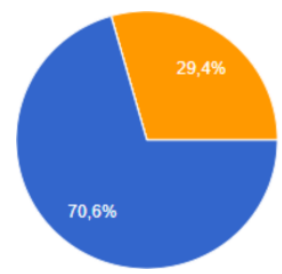

a. yes

b. nometimes

Fig. 7. The Role of Parents in Online Learning

Based on the results of the questionnaire in Fig. 7, that most students get support and encouragement from their parents in the implementation of online learning of PJOK. 70.6\% of parents support and help students in online learning of PJOK, while $29.4 \%$ of parents sometimes help students in online learning of PJOK.

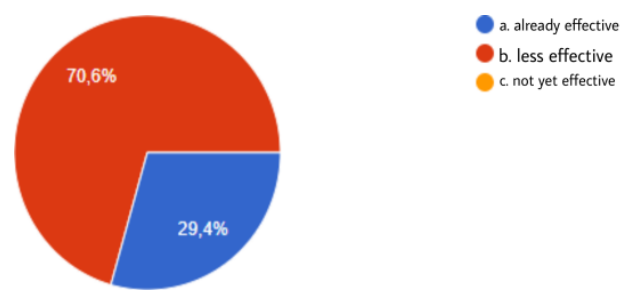

Fig. 8. The effectiveness of online PJOK learning

Based on Fig. 8, that most students (70.6\%) felt that online learning of PJOK was not as effective as offline learning of PJOK. However, 29.4\% of students feel that online sports learning has been effective.

Class conditions that are different from conditions at home are one of the main factors that affect make it difficult for students to concentrate, feel bored, and feel lazy when studying online. By Therefore, the role of parents is very important in encouraging students so that students can create a comfortable and supportive environment during the implementation of online learning activities. During the corona virus pandemic, students say online learning of PJOK is not fun because exercising alone at home makes students bored (41.2\%), the subject matter is difficult understood (23.5\%), and limited sports equipment and land make students lazy to exercise $(11,8 \%)$, difficulty concentrating, and other reasons. Learn more about PJOK at school fun than online learning because students can meet and do sports with friends (76.5\%), a large environment for exercise (17.6\%) and can interact directly with the teacher $(5.9 \%)$.

Volume 3, Nomor 1, Maret 2022 | 25 
In the following, observers attach some photos of activities carried out during observations regarding PJOK Online Learning.
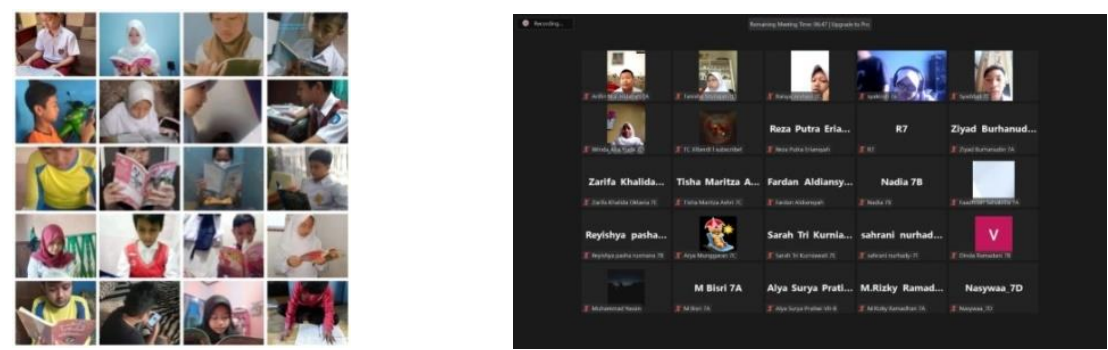

Fig. 9. Reading and Writing Literacy Activities and PJOK Zoom Meeting

This PJOK learning activities begins with students doing Literacy related to the material to be studied. Then some material is recorded, especially material that students do not understand. After the students have done literacy, the next activity is a Zoom Meeting with the PJOK lesson teacher so that students get an understanding of the material they have just read. The teacher confirms the material that the students have read and explains things that are not understood by the students.

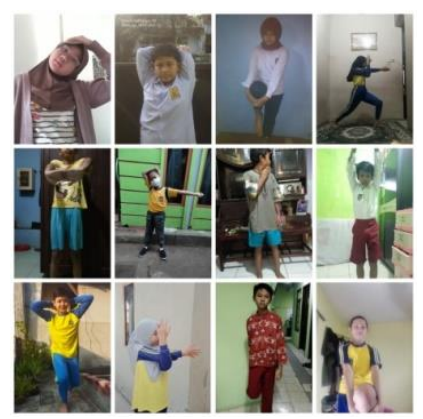

Fig. 10. PJOK Learning Activities conducted by Class 7 students online

The last activity, after doing the Literacy and Zoom Meeting and the students have understood the material, then the students apply or do the sports movements at home independently. This activity must be carried out by students so that their bodies can be maintained properly during the Covid-19 pandemic even though this learning is done online.

\section{Conclusion}

From the results of online questionnaires or questionnaires, most of the 7th grade students of SMPN 4 Bandung have difficulty in online learning of PJOK because they cannot interact directly with the teacher and cannot exercise with their friends. Other than that, online Learning of PJOK according to students is less fun, and learning material spoorly

Volume 3, Nomor 1, Maret 2022| 26 
understood due to the lack of direct interaction between teachers and students, especially for PJOK which is usually done directly (practice). More Offline Learning liked by students is still a student's hope which until now has not been able to be done because still in the time of the Covid-19 Pandemic. The results of the study concluded that students' difficulties in when online learning of PJOK is influenced by several factors, namely student motivation, tools, and a large area for students to do sports, direct interaction between teachers and students, and material that is not understood by students. In addition, the role of parents is also very important to encourage students to remain enthusiastic about learning PJOK even though it is online.

\section{Acknowledgement}

This activity is a part of community service in the Program: KKN Thematic Literacy 2021 (26 August 2021 - 26 September 2021) Kelompok 20, Lembaga Penelitian dan Pengabdian Masyarakat (LPPM), Universitas Pendidikan Indonesia. The author's deepest gratitude goes to all those who played a role in making articles and implementing the MBKM UPI Thematic KKN, especially the principal of SMPN 4 Bandung, Mrs. Dra. Hj. Sringatun, M.M who has given me the opportunity to carry out KKN, PJOK teacher at SMPN 4 Bandung, Mr. Acep Abdurahman, M.Pd, who has guided me during KKN at school, and Class 7 students of SMPN 4 Bandung.

\section{References}

Azhar, F. M. \& Maryanti, R. 2021. Response of Junior High School Students on Online Learning in Suppressing the Spread of COVID-19. Indonesian Journal of Educational Observation and technology. 1(2), 87-94.

Herlina \& Suherman, M. 2020. Potensi Pembelajaran Pendidikan Jasmani Olahraga Dan Kesehatan (Pjok) Di Tengah Pandemi Corona Virus Disease (Covid)-19 Di Sekolah Dasar. Tadulako Journal Sport Science And Physical Education. 8(1), 1-7.

Latifah, S, L. \& Priambodo, A. 2021. Perbandingan Tingkat Motivasi Selama Pembelajaran Daring Dan Luring Pada Materi Bola Voli Di SMKN 1 Kanor. Jurnal Pendidikan Olahraga dan Kesehatan, UNESA. 9(2), 359-364.

Mansyur, A. R. 2020. Dampak COVID-19 Terhadap Dinamika Pembelajaran Di Indonesia. Education and Learning Journal. 1(2), 113-123.

Ramadhona, H. 2016. Pemanfaatan E-Learning Berbasis Moodle Pada Pembelajaran Sepakbola. Prosiding Seminar Nasional Peran Pendidikan jasmani Dalam menyangga Interdisipliner Olmu Keolahragaan, 2016. 
Rozi, F. dkk. 2021. Tiga Aspek dalam Pembelajaran Pendidikan Jasmani pada Masa Pandemi Covid-19. Jurnal Kependidikan: Jurnal Hasil Penelitian dan Kajian Kepustakaan di Bidang Pendidikan, Pengajaran dan Pembelajaran. 7(1), 239-246.

Santoso, B. (2020). Prosach: Sebagai acuan pembelajaran matematika dengan menggunakan platform digital di masa pandemik covid-19. Linier: Journal of Mathematics Education. 1(1), 51-56.

Sari, D. P. \& Sutapa, P. 2020. Efektivitas Pembelajaran Jarak Jauh Dengan Daring Selama Pandemi Covid-19 Mata Pelajaran Pendidikan Jasmani Olahraga Dan Kesehatan (PJOK). Pendidikan Jasmani Olahraga dan Kesehatan, 1(1), 1-11.

Yulianto, I. D. 2021. Survei Pelaksanaan Pembelajaran Penjas Dalam Situasi Pandemi Covid 19 Di SMP Negeri/SederajatSe-Kec.Karangkobar. Indonesian Jurnal For Physical Education And Sport. 2(1), 373-379.

Yunitasari, R. \& Hanifah, U. 2020. Pengaruh Pembelajaran Daring terhadap Minat Belajar Siswa pada Masa COVID-19. EDUKATIF: JURNAL ILMU PENDIDIKAN, Universitas Pahlawan. 2(3), 232-243. 